\title{
Search for Identity in Modern Foreign Policy of Lithuania: between the Northern and Eastern dimensions?*
}

\begin{abstract}
The article attempts to look at foreign and security policy of independent Lithuania as a state identity formation process. The analysis is based on social constructivism methodology, underlying the predominant role of immaterial factors in the development of international system. The article begins with the presentation of the Lithuanian geopolitical environment as an interaction of differently constructed identities. In this context, the place and role of Lithuania in the Northern dimension of the EU before and after the EU membership is analyzed. In analyzing Lithuanian foreign policy landmarks after the double enlargement, a wider survey of problems and perspectives of its participation in the latest EU foreign policy initiatives and its relationship with the EU Eastern dimension is given. The article states that Lithuania, trying to become the center of regional cooperation, is creating a civil state identity assembling other states by force of the example to be followed. However, the regional identity of Lithuania is still under formation: pretensions to unite the North, South and East are conceptually not grounded enough and the narrative uniting the region is still at an embryonic stage. In its position Lithuanian foreign policy substantiation is closer to the EU Northern and not Eastern dimension.
\end{abstract}

We're in NATO already, see the world differently ready ${ }^{l}$

\section{Introduction}

Beginning the existence of Lithuania as a fully-fledged NATO and the EU State, May 2004, as if divides modern Lithuanian history into two parts: before and after the membership. This new state development stage inevitably raises substantiation issues concerning the fundamentals of the statehood, the aims and role of the state in the new situation. It is not by chance that the Lithuanian political discourse asserts dominance over politics reconceptualization issues which practically manifest themselves by reviewing previously formulated strategic documents (The Law on the Basics of Security, Foreign policy conception) involving sufficiently wide society

\footnotetext{
"Doc. dr. Gražina Miniotaite - is associated professor of the Political Science Department of the Lithuanian Military Academy and a researcher of the Culture, Philosophy and Arts Research Institute. Address: Šilo 5a, LT-10322 Vilnius, Lithuania tel. +370-5-2103569, e-mail: grazinam@ktl.mii.lt

** Author is grateful to the colleagues of the COST Action 24 for inspiring research assistance. I am especially indebted to Pertti Joenniemi for comments on an earlier draft of this paper.

${ }^{1}$ Website motto of Lithuanian Youth Organizations, http://www.lijot.lt/nato , 14082004.
} 
layers into discussions. State and scientific institutions, mass media speak about the necessity to formulate and substantiate new foreign and security policy of Lithuania taking into consideration the changed status of the state. However, have the 2004 treaties truly established a new state? Is the Lithuania of 2004 different from that of 2003? Questions like these point to the problematic analysis of the changing state. Analysts of international politics emphasize that the change of the state cannot be explained as a substitution of one object possessing certain characteristics by another, it is a process which gives birth to a new quality. Regarding this a question arises how to describe and analyze a process? This is one of key questions of recent years in the theoretical studies of international relations.

Attempts to conceptualize reality as a process, "capture" its mobility, fluidity and change ${ }^{2}$ are characteristic of all social sciences, attempting to get free from long-dominant positivist epistemology and objectivist ontology. In the analysis of international relations, alongside the established rationalistic theorization, explaining social reality as an interaction of constant objects with fixed characteristics (realism, neorealism, neoliberalism), the so-called reflectivist theories (constructivism, feminist theories, normative theory, critical theory and historical sociology), underlying the constitutive nature of reality are gaining ground ${ }^{3}$. Methodological turn to the reality-process analysis require a new conceptual apparatus, the development of which is still in formation. In developing new analysis instruments, postmodernist philosophies and contemporary linguistic insights are invoked: social reality is analyzed as discoursive space, as a speech act, as a communicative action. To express the changing reality either new concepts are coined or a new content is attached to the established ones. Particular attention and new conceptualization were given to the concept of collective (state) identity: "A world without identities is a world of chaos, a world of pervasive and irremediable uncertainty, a world much more dangerous than anarchy", Non enduring political order can exist without a substantial sense of community and shared identity"4. These citations reflect the fact that after the cold war in both domestic and foreign policy of states the mobilizing group identity function is particularly actualized.

All theoretical analyses perspectives of international relations acknowledge the presence of a link between the state identity and its foreign-security policy, but the actualization of this connection is largely referred to social constructivism methodology. At least several rather different variants of constructivism exist; they share a common attitude towards the international community as an interaction of intersubjectively constructed identities. As A. Wendt points out: "The rationalist strategy treats identities and interests as exogenously given and constant, and focuses on the factors shaping actors expectations about each other's behaviour. The constructivist strategy treats identities and interests as endogenous to interaction and thus a dependent variable in process. Structural change occurs when actors redefine who they are and what they want"s.

\footnotetext{
${ }^{2}$ Albert M., Jacobson D., and Lapid Y., eds., Identities, Borders, Orders: Rethinking International Relation Theory, Minnesota: University of Minnesota Press, 2001, p. 2.

${ }^{3}$ For more about new theoretical approaches see: Smith S., "New Approaches to International Theory", in: Baylis J., Smith S., eds., The Globalization of World Politics, Oxford: Oxford University Press, 1997, p. 165-190.

${ }^{4}$ Albert M., (note 2), p. 15.

${ }^{5}$ Wendt A., Social Theory of International Politics, Cambridge: Cambridge University Press, 1999, p. 336-337.
} 
The precondition for the existence of both individual and group identity is the separation of Self (inside) and Other (outside). The existence of collective identity depends on the capability of the group to maintain the sense of community and constantly reproduce its solidarity history, defining the group in a certain space and time. ${ }^{6}$ The conception of identity dominating in the state is formed of a multitude of possibilities and eventually establishes itself as the story of dividing the world into selves and others, otherwise - the narrative. The concepts of the nation, national interest, national security acquire significance only due to the group-unifying narrative. The narrative is the main form representing group identity? ${ }^{7}$. Using Foucault terminology, group identity can be defined as a discoursive formation, manifesting itself through different discoursive practices. In their turn, discoursive practices generate narrative structures that have a constitutive influence on political processes ${ }^{8}$. In modern narratology the analysis method of group identity expressing narratives is deconstruction disclosing binary oppositions lying in them: inside/outside, self/other, identity/difference, individuality/universality ${ }^{9}$.

From the conception of identity as a discoursive formation ensues the conclusion that "National states do not possess prediscoursive, stable identities. States are never finished as entities, the tension between the demands of identity and the practices that constitute it can never be fully resolved, because the performative nature of identity can never be fully revealed. This paradox inherent to their being renders state in permanent need of reproduction: with no ontological status apart from the many and varied practices that constitute their reality, states are (and have been) always in a process of becoming"10 . A state is "a constant political problem"11. Key practices of state identity construction are foreign and security policy ${ }^{12}$. In the history of any state is the period of the establishment of the narrative substantiating its identity during which new metaphors and rules stabilizing identity are formed. For the formation of the Lithuanian identity, the essential metaphor is "return to Europe" (the Western world), which is directly linked to NATO and the EU membership aspiration process. By producing clear membership criteria, NATO and the EU had (and still have) a great impact on the formation of the identity of Lithuania ${ }^{13}$.

The article attempts to cast a glance at the foreign and security policy of independent Lithuania as at the state identity formation process. It is mostly based on the methodology of social constructivism, focusing on the dominant role of immaterial factors in the development of the international system. The article starts with the pre-

\footnotetext{
${ }^{6}$ McSweeney B., Security, Identity and Interests: A Sociology of International Relations, Cambridge: Cambridge University Press, 1999, p. 163.

${ }^{7}$ For more see: Currie M., Postmodern Narrative Theory, New York: St. Martin Press, 1998.

${ }^{8}$ See: Halabi Y., "The Expansion of Global Governance into the Third World: Altruism, Realism or Constructivism?", International Studies Review, 2004 (1), p. 35-38.

${ }^{9}$ See: Currie M., (note 7), p. 73-95.

${ }^{10}$ Campbell D., Writing Security: United States Foreign Policy and the Politics of Identity, Manchester: Manchester University Press, 1992, p. 11.

${ }^{11}$ Devetak R., "Postmodernism", in: Burchill S. and Linklater A., eds., Theories of International

Relations, New York: St. Martin Press, 1995, p. 200.

${ }^{12}$ For more see: McSweeney B. (note 6).

${ }^{13}$ See: Maniokas K., EU Enlargement and Europeanization, Vilnius, Eugrimas, 2003.
} 
sentation of the Lithuanian geopolitical environment as an interaction of differently constructed identities. In this context, the article analyzes the place and role of Lithuania in the Northern dimension of the EU before its membership in NATO and the EU and after it became a fully-fledged member of these organizations. Further, while analyzing landmarks of Lithuanian foreign policy after the double enlargement, a closer look is given to perspectives and problems of its participation in the latest EU foreign policy initiatives and its relation to the Eastern dimension of the EU.

\section{Identity of Lithuania and its Foreign and Security Policy}

After the restoration of independence, in substantiating foreign and security policy, Lithuania followed the continuity of the interwar Lithuanian state. No wonder that it oriented towards the so-called then dominating model of the Westphalian States system, in which identity is stabilized as a nation state, borders as clearly defined territorial lines and order as a stable distribution of power among sovereign states ${ }^{14}$. In the Westphalian model, sovereignty is the fundamental principle organizing a modern political system, in which the preservation of territorial sovereignty is the key task of security and foreign policy. This system remained dominant until the end of the cold war; the essential distinctions that constitute it are "inside/outside", "anarchy/hierarchy", "self/other"15.

Strategies of foreign and security policy in a concrete state are formulated in reference to the interpretation of Other and outside. As proved by different studies deconstructing the neo-realistic conceptualization of the reality, Other in a modern system of states is constructed as a threat ${ }^{16}$. The world is divided into a safe, rationally controlled inside of the nation state and dangerous, anarchic, unpredictable outside, into peace and threat zones. It is this conception of international relations that is provided for in The Basics of the National Security of Lithuania ${ }^{17}$. Characteristic of the political discourse of Lithuania and likewise of other post-soviet area states is a certain tension between the identity of the nation state and integrative practices of its foreign policy ${ }^{18}$. Nation state identity requires exclusion or identity policy ${ }^{19}$, whereas the key objective of foreign policy -("return to Europe" or to the Western security community) -inclusion or the integration policy ${ }^{20}$. Therefore, in the article the modern political identity formation process is analyzed as the correlation of the nation state (sovereignty) and integration discourses. Nodal points of the discourses are different conceptions of Europe and Russia.

After the end of the cold war, with the shaping of a new world order, identity reconceptualization and reformulation of foreign policy objectives became an urgent task for all participant of the Lithuanian security area. This is reflected in the estimations of the involvement of Lithuania and other Baltic States, after a 50-year interval, into the big politics of Europe. Lithuania interpreted this fact as the restoration of historical justice, return to Europe, from which it was brutally torn away in 1940. It is no

${ }^{14}$ Albert M., Jacobson D., Lapid Y., (note 7), p. 7-8.

${ }^{15}$ Ibidem, p. 11.

${ }^{16}$ See: Bartelson J., A Genealogy of Sovereignty, Cambridge: Cambridge University Press, 1995;

Biersteker J. T., Weber C., eds, State Sovereignty as Social Construct, Cambridge: Cambridge

University Press, 1996. 
wonder that at first, its objectives of foreign and security policy were formulated by using concepts of the nation state discourse, focusing on the threatening nature of the environment. In the West the return of the Baltic States onto the map of Europe is most frequently treated as the confirmation of the power of the West, its victory in the cold war. However, the position that the end of the cold war and geopolitical changes related to this are proof of the importance of ideas and normative factors in the historical process is gaining ever increasing weight. Specifically, new possibilities for the development of liberalism values and security community are considered ${ }^{21}$. In Russia, dual estimation of the independence of the Baltic States is also clear-cut. At first, the position that the independence of the Baltic States was the loss of very important territories, the indication of the weakness of Russia as a state became dominant. Correspondingly, in foreign and security policy attempts are made to preserve the influence on the Baltic States; they are defined as "the near abroad", as the area of particular interests of Russia. Alongside this standpoint exists a still less popular though more promising position that the recognition of the independence of the Baltic States is a significant premise of the democratization of Russia and its rapprochement with the West.

In 1994, when the Baltic States joined the NATO Partnership for Peace Program and expressed their wish to become fully-fledged members of NATO and the EU, the Baltic dimension became a significant part of debates on the security of Europe. At that time, both the West and Russia and Lithuania faced the so-called Baltic security dilemma for the solution of which, according to the apt expression of Karl Bildt, the then Prime-Minister of Sweden, like a litmus test indicated the capability of different states to coexist peacefully under the new conditions ${ }^{22}$. The origin of the Baltic dilemmas, defined as the necessity to coordinate rather contradictory interests of the Baltic States, the West and Russia, lie in different security conceptualizations. At that time, in security and foreign policy of Lithuania an instrumental interpretation of the integration with the West dominated and the membership in NATO and the EU were means to safeguard the sovereignty of Lithuania from unpredictable and threatening Russia. The emergence of the Baltic dimension in the politics of Europe made the relations of Western States with Russia most problematic. A determined aspiration of Lithuania to become a member of NATO was perceived in Russia as a challenge for its national

\footnotetext{
${ }^{17}$ See: Miniotaite G., "The Baltic States: In Search of Security and Identity" in Krupnick Ch., ed., Almost NATO: Partners and Players in Central and Eastern European Security, Lanham, Md: Rowman \& Littlefield, 2003, p. 261-296.

${ }^{18}$ See: Smith G., Law V., Kuus M., "Toward Cooperative Security? International Integration and the Construction of Security in Estonia”, Millennium: Journal of International Studies, 2002, 31 (2), p. 297-317;

Miniotaite, G. "The Security Policy of Lithuania and the "Integration Dilemma", COPRI Working Papers, 2000 (5).

${ }^{19}$ The concept "identity policy" is rather widely used in the analysis of modern political processes. See: Wilson A., Bohr A. and E. Allworth, Nation-Building in the Post-Soviet Borderlands: The Politics of National Identities, Cambridge: Cambridge University Press, 1998.

${ }^{20}$ As Peter van Ham and Przemyslaw Grudzinski point out, the tension between identity and integration politics is characteristic of all post-Soviet European States. See: Ham van P. and Grudzinski P., "Europe's New Sphere of Affluence", "The National Interest", Winter 1999/2000 (58).

${ }^{21}$ See: Adler, E. and Barnett, M., eds., Security Communities, Cambridge: Cambridge University Press, 1998.

${ }^{22}$ See: Carl Bildt, "The Baltic Litmus Test", Foreign Affairs, 1994 (5), p. 73.
} 
interests and a source of tension with NATO countries. The West, however, from the very start, tried to review the traditional model of their relations with Russia. Seeking to support the democratization processes in Russia, they attempt to develop a common values-related area including both the Baltic States and Russia. After the accession of Sweden and Finland to the EU, the situation of the Baltic dilemma becomes a part of the Northern dimension of the EU foreign policy.

\section{The Northern Dimension of the European Union and Foreign Security Policy of Lithuania}

After Sweden and Finland joined the EU in 1995, and Russian-Finnish border became the Eastern border of the EU, the Northern direction in the foreign policy of the EU acquired an independent meaning. In 1997, Finland offered the EU the Northern Dimension Initiative (NDI) that has been an official part of the policy of the European Union since 1998. The Northern dimension can be considered the coordinator of the institutions already existing in the region for the financing of the programs of the Baltic Sea States Council and the EU ${ }^{23}$. The official objective of the Northern dimension is the promotion of horizontal cooperation between the actors of Northern Europe. Particular attention is focused on economic, social and environmental protection problems. 11 North-Eastern European States participate in the activity: Denmark, Estonia, Iceland, Latvia, Lithuania, Poland, Norway, Russia, Finland, Sweden and Germany.

NDI activity comprises the Baltic region that in academic literature is often defined as the area of the interaction between modern and postmodern policy ${ }^{24}$. Underlying decentralization, the importance of horizontal relations, fragmentation and tolerance, the Northern States are closer to postmodernist policy which, while acknowledging the complexity and relativity of reality, rejects epistemological optimism, characteristic of the modernity epoch, and the aims closely linked with it to completely control and predict social environment. The concept of the territoriality acquires a new sense - the conception of the border separating one state from another is replaced by the concept of the boundary unifying states ${ }^{25}$. In suiting its own aims, Lithuania, like other post-soviet region states, by the treatment of the surrounding area is closer to modern sovereignty policy, which typically contrasts inside and outside. Russia also describes its interests in the region (preservation of territorial integrity, maintaining of military balance existing in the region) by using modernity discourse concepts. In the modernist narrative of Russia, the Baltic States are treated as lost territories, thus complicating the recognition of them as equal partners ${ }^{26}$.

\footnotetext{
${ }^{23}$ Well before the beginning of the initiative such regional institutions as the Council of Baltic Sea States, the Nordic Council, the Barents Euro-Arctic Council functioned in Northern Europe.

${ }^{24}$ See: Lehti M., \& Smith D., eds., Post-Cold War Identity Politics: Northern and Baltic Experiences, London: Frank Cass, 2003; Hanse L., \& Waever O., eds., European Integration and National Identity: the Challenge of the Northern States, London \& New York, Routledge, 2002.

${ }^{25}$ See: Friis L. and Murphy A., "The European Union and Central and Eastern Europe: Governance and Boundaries", Journal of Common Market Studies, 1999, 37(2), p. 211-32.

${ }^{26}$ See: Morozov V., "The Baltic States in Russian Foreign Policy Discourse: Can Russia Become a Baltic Country?”, Marko Lehti \& David Smith (eds.), (note 24), p. 239-240.
} 
The States of the Baltic Sea region joined the NDI seeking rather different aims. Finland and Sweden sought to strengthen their weight within the European Union, Norway and Iceland wanted a closer cooperation with EU institutions, Poland, Latvia, Lithuania and Estonia hoped that their participation in the initiative would bring them nearer to the EU membership and strengthen their security. Russia estimated its joining the initiative rather ambiguously, discerning in the Northern dimension either the aspiration of the West to delimit the Kaliningrad region from Russia or new possibilities for cooperation with the West by becoming the Russian gateway to the European Union ${ }^{27}$. Most probably because of the cultural, political and economic diversity of participants, the Baltic region came to be called the EU laboratory, the training area where EU governance models are tested and approved. The metaphor of the laboratory, that many people became fond of, can be interpreted in different ways. Firstly, the metaphor of the laboratory reveals that it is not a naturally emerging region, but rather a common area organized "from above". In creating the narrative unifying the region, this area is provided a particular "naturalness" by the Baltic Sea and historical interpretations of peaceful cooperation related to it. Secondly, the metaphor of the laboratory, where the experiment of the coexistence of diversities is under way, inevitably leads to the question - what is the relation between the experiment originators and its participants? Are the declared horizontal relations possibly only an illusion or would a closer look reveal the hierarchical structure of the region? Answers to these questions lie in the specificity of the region. Not only the foregoing 11 States but also the European Union as a totality operate in the region.

The European Union is not a normal state, it is a transnational political system $^{28}$, "civilian power" 29 , whose international authority lies not in the military but political and economic power. By transforming the environment it creates a common economic, political and values-related area. As its economic achievements and peaceful foreign policy appeal to other states, the EU becomes a model to follow, thus exerting influence on the international environment. The EU approves of the Finnish initiative to expand the Northern region; in fact the Baltic and Northern regions overlap in its creation. In the construction of the Northern region, the experience of the cooperation of Nordic States and governance models, previously applied by the EU, integrate. The first and the second Northern Dimension Action Plans are adopted and executed. ${ }^{30}$ The implementation of the plans is based on individual EU agreements with each participating state ${ }^{31}$, financing sources being various EU programs ${ }^{32}$

\footnotetext{
${ }^{27}$ See: Joenniemi P., Sergounin A., Russia and the European Union's Northern Dimension, Nizhny Novgorod: Nizhny Novgorod University Press, 2003.

${ }^{28}$ Moravcsik, A., The Choice for Europe. Social Purpose and State Power from Messina to Maastricht, Ithaca/New York: Cornell University Press, 1998, p. 1.

${ }^{29}$ See: Hill C., "Closing the capabilities-expectations gap?", In Peterson J., Sjursen H., eds., $A$ Common Foreign Policy for Europe? Competing visions of the CFSP, London and New York: Routledge, 1998, p. 91-107.

${ }^{30}$ The First Northern Dimension Action Plan, 2000-2003:

http;//europa. eu.int/comm./external_relations/north_dim/ndap/06_00_en.pdf. 12072004.

The Second Northern Dimension Action Plan, 2004-2006:

http://europa.eu.int/comm/external_relations/north_dim/ndap/com03_343.pdf . 12072004.

${ }^{31}$ Cooperation with Iceland and Norway is based on the Economical Area Agreement, with the Baltic States and Poland - the European Agreement, with Russia - the Partnership Cooperation Agreement.

32 INTERREG, Phare, TACIS, ISPA and SAPARD programs participate in the financing of the

Northern Dimension Action Plans.
} 
and cooperation partners ${ }^{33}$. The Northern Dimension Initiative functions as an EU instrument providing the form for the cooperation of the region participants. Coming back to the region - the metaphor of the laboratory, it is possible to state that this concept, derived from the modernity discourse, is granted a postmodernist content: the laboratory where diversities coexist gives birth to a certain, organizing the EU and the surrounding area model, which is created by all participants in the region.

What is the role of Lithuania in this "laboratory" of the Northern European region? In 1997, after Estonia was invited to start membership negotiations with the EU, and the neighbouring Poland with NATO, Lithuania's membership in these organizations also acquired sufficiently real contours. To be invited to negotiations with the EU did not seem to encounter any particular outside obstacles; it was only necessary to persuade the European Commission and the EU member States that Lithuania meets Copenhagen criteria. Meanwhile, Russia was actively opposed to the NATO membership and proposed alternative security variants ${ }^{34}$. Besides, Western states had no unanimous opinion related to the issue of NATO membership of the Baltic States. Thus, having joined the Northern Dimension Initiative in 1998, Lithuania considered its membership in it as an important instrument for the implementation of key objectives of foreign policy, i.e. EU and NATO membership, and good neighborly relations. Participation in the NDI offered an opportunity to Lithuania to come closer to EU institutions, gain regional cooperation skills and contribute to the Russia's integration into the region.

The majority of the states involved in the NDI border on Russia, however, a comparatively short land border of Lithuania with the Kaliningrad region of Russia is of utmost importance to Russia and the whole region. After the collapse of the Soviet Union and restoration of the independence of Lithuania in 1991, Russia lost its territorial integrity. Ties of the smallest and the most backward Kaliningrad region (out of 89) with Russia became dependent on its transit (military, economic, movement of persons) through Lithuania. Not surprising, Russia sought and is seeking to retain its political and economic influence in Lithuania. The position of Lithuania regarding the border with Russia changed depending on the relations between NATO and Russia as well as on the EU policy in regard to the region. At first, the militarized Kaliningrad region was perceived as a direct military threat to the independence of Lithuania. In 1994, the issue of the threat of Kaliningrad was made particularly acute. It was addressed at the Baltic Assembly, the program of the Government of Lithuania. In the same year, the adoption of regulations on the transit of military and dangerous cargoes through Lithuania was followed by severe criticism from the opposition, fears about a possible loss of sovereignty ${ }^{35}$.

\footnotetext{
${ }^{33}$ Cooperation partners are the European Bank for Reconstruction and Development, the European Investment Bank, the World Bank, the U. S. Northern European Initiative and others.

${ }^{34}$ After the rather unfavourable for the Baltic States results of the NATO summit meeting in Madrid (1997) and before signing the USA-Baltic Charter (1998), Russia submitted suggestions on security guarantees for the Baltic States. These suggestions particularly emphasize the non-alignment of the Baltic States to military blocks, the importance of the policy of neutrality. It is proposed to establish Russian security guarantees by a bilateral agreement between the Baltic States and Russia. The Baltic States unanimously rejected these proposals by Russia.

${ }^{35}$ Sirutavičius V., Stanytė-Toločkienè I., "Strategic Importance of the Kaliningrad Oblast of the Russian Federation", Vitkus G., ed., Lithuanian Annual Strategic Review 2002, Vilnius: Lithuanian Military Academy, 2003, p. 193.
} 
This attitude towards the Kaliningrad region as a source of constant threat to the independence of Lithuania also found its expression in the Law on the Basics of National Security of Lithuania approved at the end of $1996^{36}$. Gradually, this position of "hard" security was replaced by the standpoint of "soft" security - in the National Security Strategy approved in 2002, the issue of Kaliningrad was conceptualized not as a threat to Lithuanian security but as a common issue of the region. In its relations with the Kaliningrad region Lithuania is seeking "the promotion of good neighbourly relations, and economic, trade, and cultural partnership, and improving economic development and standard of living so that it compares more favourably with neighboring states, particularly those approaching the EU membership" ${ }^{37}$. One can agree with the authors of the study on the Kaliningrad region that "during the last decade, $\mathrm{KO}$ underwent transformation in the foreign policy of Lithuania: from the main threat to security into an advantage - an opportunity to play an independent role of the leader in the south-east of the Baltic Sea region, truly contributing to promotion of stability in the area" ${ }^{38}$. Participation of Lithuania in the NDI had a great impact on the transformation Lithuania's position concerning the significance of the Kaliningrad region.

In the framework of the NDI, Lithuania actively participates in the integration of the Kaliningrad region into Northern European projects dealing with problems of energy, transport, border crossing and environmental protection. In 1998, a working group for promoting cooperation between regions of Lithuania and the Kaliningrad region was formed under the Lithuanian-Russian Intergovernmental Commission, and in 2000, the Council for Long-term Cooperation between Lithuania and the Kaliningrad Region was established. Lithuania and Russia put forth joint proposals for the first and the second NDI action plans. At the beginning of 2000, they jointly submitted to the European Commission 15 common projects on transport, energy, environmental protection, health care, etc. They were called the "Nida Initiatives" and are implemented from the public funds of each country as well as from funds of mutual assistance and EU programs. The Nida Initiative was the first joint Lithuanian-Russian initiative. At the NDI conference held in April 2003, for the second NDI action plan Lithuania and Russia submitted the Nida 2 Initiative which consists of 5 supplemented and renewed projects on cooperation with the Kaliningrad region comprising the issues of transport, environmental protection and social problems. Lithuania takes part in the activity of Euroregions Nemunas (established in 1997), Baltija (1998), Saule (1999) and Šešupé (2003). The regions encompass municipalities of Lithuania, the Kaliningrad region, Belarus, Poland, Latvia, Sweden ${ }^{39}$.

After the accession of Lithuania to NATO and the EU, its relations with Russia have become part of relations between the EU and Russia. After signing the

\footnotetext{
${ }^{36}$ See: "The Law on the Basics of the National Security of the Republic of Lithuania" adopted on 1912 1996, Valstybes žinios, 1997 (2), p. 2-20.

${ }^{37}$ The National Security Strategy, 2002, http://www.kam.lt/catalog/ministerija/nacionalinio saugumo strategija 06 05.doc., 01082004.

${ }^{38}$ Sirutavičius V., Stanytė-Toločkienė I., "Strategic importance of the Kaliningrad Oblast of the Russian Federation", (note 35) p. 186.

${ }^{39}$ More on participation of Lithuania in the activity of Euroregions, see: Euroregionai, http:// www.urm.lt/data/5/LF2129325 kalin-.html.
} 
EU-Russia Agreement on Russian transit from the Kaliningrad enclave through Lithuanian territory in the end of 2002, in 2003, Russia ratified the long-delayed Treaty on the Lithuanian-Russian State Border and signed a readmission agreement. Stricter regulations on transit of Kaliningrad region citizens via Lithuania (visa regime) that came into effect on 1 July 2003, brought Lithuania closer to the Schengen Treaty regulated space without causing a major deterioration in the relations between Lithuania and Russia ${ }^{40}$. In the political discourse, the Kaliningrad from a problem turned into "a window of opportunity" for diversity of regional cooperation forms ${ }^{41}$. Lithuania proved to be capable of creatively implementing the cooperation model proposed by the EU. This had an impact on its self-awareness in the region. The image of Lithuania as a bridge between the East and the West was replaced by the images of the bridgehead between Lithuania and the West and, eventually, the outpost of Western values ${ }^{42}$. Besides, participation in the Northern Dimension accelerated institutionalization of ES norms and regulations in the Constitution and laws of Lithuania.

In spite of successful regional cooperation experience, in the narrative of Lithuania substantiating its modern political identity belonging to the Northern region of Europe plays no major role. Unlike the Minister of Foreign Affairs of Estonia T.H.Ilves who claimed that the Northern Initiative is "a means of restoring our natural place in the Nordic space" ${ }^{43}$, Lithuanian politicians tend to define Lithuania as a state of Central Europe. At a conference on regional security issues held in 2000, Vytautas Landsbergis made a suggestion to call the Baltic region a region of the Baltic-Central Europe ${ }^{44}$. Politicians of Latvia call their country a Northern Baltic state. This suggests that the Baltic Sea States region created 'from above' does not constitute a common identity ${ }^{45}$. Having become a member of the EU and NATO, Lithuania, it seems, considers the Wider Europe New Neighborhood' initiative shaping the Eastern policy of the EU to be closer to it.

\footnotetext{
${ }^{40}$ It should be noted that the issue of the transit of Russian citizens through Lithuanian territory remains a source of potential tension between the two states. In September 2004, the Seimas of the Republic of Lithuania adopted a resolution by which it rejected the Russian proposal, rather favorably approved by some EU states, to create a corridor for transit of people and goods between the Kaliningrad region and the rest of Russia through the territory of Lithuania.

${ }^{41}$ See: Ušackas V. "Lithuania and Kaliningrad: building a partnership for the new Europe", http:// www.lt/data/3/EF31014125 0727usac.htm, 14072004.

${ }^{42}$ See: Miniotaite G. "Convergent Geography and Divergent Identities: A Decade of Transformation in the Baltic States", Cambridge Review of International Affairs, 2003, 16(2), p. 209-222; Pavlovaite I., "Paradise Regained: The Conceptualization of Europe in the Lithuanian Debate", in Lehti M. \& Smith D., (note 24), p. 199-218.

${ }^{43}$ Cited according to Ruutsoo R., "A Perspective on the Northern Dimension from the Baltic States", 2002, http://www.bd.1st.se/dimensionen/rapport/14.pdf., 13082004.

${ }^{44}$ The role of NATO in the Changing Security Environment of Europe: Materials of the Conference, Vilnius, 2000, p. 23-24.

${ }^{45}$ Carl-Einar Stalvant indicates that although the states of the region are not unanimous, several blocks of states with a similar position on the EU Constitution and governance can be identified: Estonia-Sweden-Finland, Germany-Denmark, Lithuania-Poland. See: Stalvant C.E., "Interests, Loyalties, and the Lures of Power: the Baltic Sea States in Future European Governance", Huldt B., Ries T., Mortberg J., Davidson E., eds., The New Northern Security Agenda: Perspectives from Finland and Sweden, Stockholm: Swedish National Defence College, 2003, p. 93.
} 


\section{The New Foreign Policy of Lithuania}

With the accession to the European Union and NATO, Lithuania faced the task of reformulating key foreign and security policy issues and finding its place in common foreign and security policy (CFSC) of the European Union. During the period of aspiration for the membership, domestic and foreign policy of Lithuania, like that of other candidate states, was inevitably adaptive in character. The clearly formulated requirements for the membership and a well-considered control mechanism of their implementation gave no particular space to the candidates' initiative. Restricted by the commitment to comply with acquis, to timely close down negotiations chapters or attempt at compatibility of their defense structures with those of NATO, they differed no more than in their position on the table of progress. Lithuania was among the most advanced on the way to $\mathrm{NATO}^{46}$, Estonia - to the EU. Further participating in the activity of the NDI, the new members sought a more independent and more significant role in CFSP. The Wider Europe concept formulated by the EU in 2003 put these aspirations into an institutional framework $\mathrm{k}^{47}$. The conception provided for a closer cooperation between the European Union and neighboring countries having at present no prospects of EU membership. As Javier Solana noted, "the reunification of Europe and the integration of acceding states will increase our security but they also bring Europe closer to troubled areas. Our task is to promote a ring of well-governed countries to the East of the European Union and on the borders of the Mediterranean with whom we can enjoy close and cooperative relations" ${ }^{48}$. At the beginning, the Eastern direction of The Wider Europe included Ukraine, Moldova, Belarus, later (in June 2004) it was enlarged by the Caucasus states - Armenia, Azerbaijan and Georgia.

In the concept of the Wider Europe relations with neighboring countries are proposed to be based on the already tried and tested principle of conditionality, i.e. the character of cooperation is directly related to the progress of states in carrying out democratic reforms as well as implementing human and minority rights. The capability of states to adhere to cooperation standards accepted in the international community is also taken into consideration.

The proposed format for the relations with neighbors proved to be appealing to all new member states, however Poland and Lithuania were the strongest supporters of the Wider Europe-New Neighborhood idea. In the beginning of 2003, the Ministry of Foreign Affairs of Poland submitted a document to the EU in which the main Eastern policy ideas called the Eastern Dimension were formulated. The latter, like the Northern Dimension, proposes a certain model of relations with neighbors. The document stresses that the Eastern Dimension of the EU should not compete with

\footnotetext{
${ }^{46}$ Regional Vilnius conferences which started in 1997, in 2000 joined together NATO aspirant states into "the Vilnius Ten". The Vilnius Ten includes Albania, Bulgaria, Croatia, Estonia, Latvia, Lithuania, Macedonia, Slovakia, Romania and Slovenia.

${ }^{47}$ The discussion on "The Wider Europe" policy was initiated by the United Kingdom. A comprehensive concept of "The Wider Europe" is laid in the 11 March 2003 Commission of Europe Communiqué "The Wider Europe - Neighborhood: A New Framework for Relations with our Eastern and Southern Neighbors".

${ }^{48}$ Javier Solana, EU High Representative, "A Secure Europe in a Better World”, 2006 2003, http:/ /www.foreignpolicy.org.tr/eng/articles/solana 200603.htm.
} 
the Northern Dimension but be a supplement to it. It should reflect the experience of the Northern Dimension as well as the experience of the new members of the $\mathrm{EU}^{49}$.

As Christopher Browning and Pertti Joenniemi point out, the difference between the dimensions is far greater than Polish politicians tend to think. A common objective of the Northern Dimension is "to reduce all dividing lines" and turn down the divide between The East and the West ${ }^{50}$. Seeking to create a common political area where non-member states could also influence decision-making, it includes all states of the region. The Eastern Dimension is less pretentious in its objectives. It strives to bring the EU neighbors Ukraine, Moldova, Belarus closer to the European Union standards and their membership in the EU. The reference to "Eastern" (dimension) does not imply that it performs the function of uniting the region; on the contrary, it draws a rather distinct line between Poland and states not belonging to the European Union in respect to which Poland has a civilizing function ${ }^{51}$. The key premise of Poland regarding the Northern Dimension is its position on the EU Eastern policy as prevention of potential threat from the East: "It is imperative for all of us to prevent potential negative consequences that may result from the growing modernisation gap between the EU and its Eastern neighbours. This gap might spur negative social phenomena such as migration pressures as well as provoke further frustration and anti-Western sentiments among the people of East European countries. Poland - situated on the border of the European Union - would be the first to feel the impact those negative consequences", emphasized the Minister of Foreign Affairs of Poland Włodzimierz Cimoszewicz ${ }^{52}$. One can agree with Browning and Joenniemi that in the Northern Dimension Europe is conceptualized as "the Europe of Olympic rings", whereas in the Eastern Dimension - as "the Europe of concentric circles" 53 .

Which of these conceptualizations is closer to Lithuania? It is difficult to give a definite answer to this question; the new foreign policy of Lithuania is taking but first steps. As the Minister of Foreign Affairs of Lithuania A. Valionis noted, "We still have a long way to go to fully comprehend the needs and tasks of the state" ${ }^{\text {54 }}$. Certain guidelines for this way are provided for in the Project on the Concept of Lithuanian Foreign Policy after its Accession to the European Union and NATO which was introduced to the public at a conference held in Vilnius University just a few weeks after the dual membership of Lithuania $^{55}$. Both the project and formal speeches of the officials emphasize that Lithu-

\footnotetext{
${ }^{49}$ Non-paper with Polish proposals concerning policy towards new Eastern neighbours after EU Enlargement, (January 2003), http://www.msz.gov.pl/start.php?page $=1040000001 \&$ obj display cat $=11 \&$ obj display full $=393 \&$ obj to display type $=21$. Referred to on 14072004 .

${ }^{50}$ Christopher S. Browning, "Towards a New Agenda? US, Russia and EU", the NEBI Yearbook 2003, Berlin: Springer-Verlag, 2003, p. 274.

${ }^{51}$ See: Christopher S. Browning \& Pertti Joenniemi, “The European Union's Two dimensions: the Eastern and Northern", Security dialogue, 3003, 34 (4), p. 471-472.

${ }^{52}$ Włodzimiez Cimoszewicz "The Eastern Dimension of the European Union. The Polish View." Paris, Institute of Political Science, April 22, 2004, http://www.msz.gov.pl/start.php., 15082004.

${ }^{53}$ Browning Ch. S. \& Joenniemi P., "The European Union's Two Dimensions: the Eastern and Northern", (Note 51), p. 476.

54 The Speech by the Minister of Foreign Affairs Antanas Valionis to the Heads of Diplomatic Missions of the Republic of Lithuania. Vilnius, 7 July 2004, http://www.urm.lt/., 19082004.

${ }^{55}$ In 2003, by a decree of the Prime Minister of the Republic of Lithuania Algirdas Brazauskas a working group was formed to draw up a project on the concept of the Lithuanian foreign policy after Lithuania's accession to the European Union and NATO.
} 
ania is oriented towards active foreign policy trying to become the center of the region: "My vision of Lithuania is that of a country which through the quality of its membership of the European Union and NATO and good neighbourhood policy has become a leader of the region. I have a vision of Lithuania as a center of the region with Vilnius as a regional capital", spoke then the Acting President of Lithuania Artūras Paulauskas introducing the Lithuanian Foreign Policy Concept and a new vision of Lithuania ${ }^{56}$. The Minister of Foreign Affairs of Lithuania approves of this idea: "the concept of a center of the region is, most probably, the only link to connect the present of our Euro-Atlantic membership with the future of the state; it gives ambition and solidity to our policy"57.

Naturally, a question arises - what kind of regional center is Lithuania intending to become? The answer is directly related to the concept of Lithuanian identity. In the substantiation of the new foreign policy, issues of regional identity that arose in the political discourse of Lithuania 1996-1997 gain urgency again. Then Lithuanian identity was related to the Baltic, Northern Baltic and East Central regions of Europe. In 2004, Lithuania - a member of the European Union and NATO - has "most probably the first opportunity in history to bridge the East and the West and make Lithuania a center of gravity in a geographically and culturally diverse region"58. Specifying this idea, the Minister of Foreign Affairs slightly narrows Lithuania's regional ambitions: "we must initiate and establish new regional cooperation formats uniting the states of Northern, Central and Eastern Europe. This would expand regional identity and enable to break away from the geographical framework formed in the interwar period. Strategic partnership with Poland, the Northern and Baltic Six, institutional partnership between Lithuania and Ukraine - all this could be developed by involving new areas, new partners, creating an interrelated cooperation area" 59 .

The presented quotations suggest that Lithuania attempts to be the center of a vast region encompassing states of both Northern and Eastern Dimensions. What are these pretensions based on? First, on the successfully started work. Right after the declaration of The Wider Europe initiative, Lithuania started a more active cooperation with Ukraine, Belarus, the Caucasus states and can appeal to the concrete results of that cooperation $^{60}$. Second, on "valuable experience of strengthening democracy and market economy and of developing co-operation with Euro-Atlantic structures" ${ }^{\text {.61 }}$. Third,

56 The Speech by the Acting President A. Paulauskas at Vilnius University on 24 May 2004. "On Lithuania's New Foreign Policy”, http:/www.urm.lt/data/2/LF51152557 Paulauskokalba.htm., 08 082004.

57 The Speech by the Minister of Foreign Affairs Antanas Valionis to the Heads of Diplomatic Missions of the Republic of Lithuania. Vilnius, 7 July 2004 (Note 54).

${ }^{58}$ The Speech by the Acting President A. Paulauskas at Vilnius University on 24 May 2004, (Note 56).

59 The Speech by the Minister of Foreign Affairs Antanas Valionis to the Heads of Diplomatic Missions of the Republic of Lithuania. Vilnius, 7 July 2004, (Note 54).

${ }^{60}$ On Lithuania's relations with Belarus and Ukraine see: Lopata R., "Autoritarianism in Belarus: Eventual Threats to Lithuania's Security", (note 35), p. 215-230; Understanding Belarus: Transition to Where? Proceedings of the International Conference, Vilnius, Lithuanian Military Academy, 2003 (9); Daniliauskas J., Lopata R., Sirutavičius V., Šatūnienė Ž., Vilpišauskas R., "The European Union and Ukraine: Lithuania's Viewpoint", in Jankauskas A., ed., Lithuanian Political Science Yearbook 2002, Vilnius, 2003, p. 203-246.

${ }^{61}$ The Speech by the President Valdas Adamkus in the meeting with the Heads of Foreign Diplomatic Missions in Lithuania on 14 July 2004, http://www.president.lt/lt/news.full/ 5125?PSID=42c199698aa3c9abbad8a4f6fe1114e7, 28082004. 
on successful participation in the Northern Dimension, fourth, on the non-conflict development of relations with Russia, and, finally, on the geopolitical position.

With the construction of the narrative substantiating the identity of Lithuania as the center of the region, the conception of both Lithuania and regional actors also changes. Lithuania is constructed not as a border between the Western and the Eastern civilizations but as "crossroads of civilizations" (Paulauskas), "center of gravity" (Adamkus), "symbol of the European Union and NATO that other states would seek to align with" (Valionis). In the newest conceptualization, Russia is losing the status of "ontological other of Europe" ${ }^{2}$. It is recognized as part of the common area: "Our objective is that the Kaliningrad region organically joins Europe and is, together with the whole Russia, open to Euro-Atlantic cooperation" ${ }^{63}$. Seeking to become the center of regional cooperation, Lithuania is creating the identity of the civil state bringing other states together by force of the example to be followed.

According to Marko Lehti, the narratives of the construction of the Estonian and Latvian identity and conceptualization of the area surrounding them are changing in the same direction ${ }^{64}$. The narrative of the golden age of the interwar period is replaced by a new history of success where economic reforms and knowledge society play the main role. "The Baltic tigers" challenge the existing center of Europe. The Baltic States are no longer pupils of Europe but forerunners of progress ${ }^{65}$. In one form or another, all Baltic states claim that both Europe and neighboring countries have something to learn from them; they can propose the EU concrete solutions "how to advance further to the East" ${ }^{\circ 6}$. Regarding this role of the Baltic experts, certain specialization manifested itself: Estonia revealed itself as a leader of economic reforms, Latvia - as that of finance, Lithuania - as a leader of international political initiatives. This to some extent explains Lithuania's claims to become the center of a vast region uniting the North, the East and the South. Besides, there are attempts to interpret the ambitions of Lithuania by its imperial past, recalling the history of the Grand Duchy of Lithuania and the history of the joint LithuanianPolish state ${ }^{67}$. These attempts, however, are more cultural-humanitarian by charac-

\footnotetext{
${ }^{62}$ See: Neumann, B.I., Russia and the Idea of Europe: A Study in Identity and International Relations, London, Routledge, 1996.

${ }^{63}$ The Speech by the Minister of Foreign Affairs Antanas Valionis to the Heads of Diplomatic Missions of the Republic of Lithuania (Note 52).

${ }^{64}$ See: Lehti M., "Challenging the 'Old' Europe: Estonia and Latvia in a 'New' Europe”, paper presented at the 5th Pan-European International Relations Conference "Constructing World Orders", The Hague, 9-11 September 2004. Lehti's analysis deals with Estonia and Latvia only but, in my opinion, the main conclusions of the article apply to all Baltic States.

${ }^{65}$ Ibidem.

${ }^{66}$ The Speech by the Acting President A. Paulauskas at Vilnius University on 24 May 2004, (Note 56). 67 "The Lithuanians cannot do without an empire. In respect to its policy, the GDL was ahead of the entire Western Europe and, in fact, came close to the doctrine of the freedom of conscience which, say, in the USA was declared, but which actually was not observed until the 20th century. We have experience and models how to implement multinational commonality. In the East our opportunities and possible interests are evident - South Caucasus, Central Asia (post-Soviet part) and the territory of the GDL which is still alive in the minds of many Ukrainians and Belarussians and which will not disappear for centuries to come". Beresnevičius, G. "An Empire in the East, an Empire in the West. An Outline of Geopolitics of Lithuania (1)", http://www.omni.lt. 24052004.
} 
ter; in official political discourse it is not popular to associate the ambitions of Lithuania as a regional leader with the history of its statehood ${ }^{68}$.

It is possible to state that ambitions of Lithuania to become the center of the region are based on present achievements rather than its glorious past: it has successfully implemented economic and political reforms, has consistently sought integration into Western economic and political structures. Of key importance is the fact that, having resolutely broken off relations with the Soviet Union, Lithuania managed to maintain good relations with Russia. In spite of the complicated issue of Kaliningrad, it was the only Baltic State that signed a border agreement with Russia and is successfully resolving the issues of transit and visas with the Kaliningrad region. This experience appeals to former Soviet Union republics seeking EU membership. Besides, the role of Lithuania in the region is positively assessed by the USA and the EU.

\section{Concluding Remarks}

Formulation and substantiation of the objectives of Lithuanian foreign policy are inseparable from the state identity construction process. The tension between nation state identity and integration objectives of foreign policy is characteristic of political discourse of Lithuania as well as that of other states of the post-Soviet area. Joining the integration process not only sped up the institutionalization of ES norms and regulations in the constitution and laws of Lithuania, but also contributed to the development of Lithuanian political identity. Specifically, participation in the EU Northern Dimension replaced the image of Lithuania as the bridge between the East and the West by the image of Lithuania as the bridgehead of the West. This, in its turn, changed the conceptualization of the Kaliningrad region in Lithuanian foreign security policy: from a threat to the state security it turned into a common regional problem, "a window of opportunity" bringing Lithuania closer to the European Union.

The new stage of Lithuanian statehood, which began in 2004, in both domestic and foreign policy is often characterized as a period of a vacuum of ideas. It lacks a common goal uniting political forces of different orientation. The new project on the concept of the Lithuanian foreign policy proposing the idea of Lithuania as the regional center is trying to fill this vacuum. The content of the concept project rather consistently follows from the already launched regional cooperation initiatives. Seeking to become the center of regional cooperation, Lithuania is creating the identity of the civil state, bringing other states together by force of an example to be followed.

Membership of the EU and NATO offers wider opportunities for active Lithuanian foreign policy, however by itself it does not make Lithuania a center of the

\footnotetext{
${ }^{68}$ It is interesting to note that the Minister of Foreign Affairs of the Republic of Poland Włodzimierz Cimoszewicz substantiating pretensions of Poland as the leader of the Eastern Dimension does not avoid appealing to historical sources of common regional identity: "For more than three centuries Poles lived in one state with Lithuanians, Ukrainians and Belarussians. Two hundred years ago that common state disappeared from the map of Europe. Yet people living on the territories of the partitioned Commonwealth never lost the western part of their identity", Włodzimierz Cimoszewicz, Minister of Foreign Affairs of the Republic of Poland, "The Eastern Policy of the European Union", Paris, Institute of Political Science, April 22, 2004, http:/www.msz.gov.pl/start.php., 10 082004.
} 
region. Judging by the documents and official speeches reviewed in the article, regional identity of Lithuania has just begun to develop, pretensions to bring together the North, the South and the East lack sufficiently well-grounded ideas, whereas the narrative uniting the region is still in embryo. Attempts to formulate the new Lithuanian foreign policy are oriented towards both the EU Northern and Eastern Dimensions: by the conceptualization of the political environment it is closer to the Northern Dimension (the Europe of Olympic rings), while by the objectives to the Polish variant of the Eastern Dimension. This indicates that Lithuanian foreign policy is poised between modern and postmodern conceptualization of political processes. 